\title{
Identification of nine species of the Chlamydiaceae using PCR-RFLP
}

\author{
Karin D. E. Everett† and Arthur A. Andersen
}

Avian and Swine

Respiratory Diseases Research Unit, National Animal Disease Center, Agricultural Research Service, US Department of Agriculture, PO Box 70, Ames, IA 50010, USA

\author{
Author for correspondence: Karin D. E. Everett. Tel: +1 706542 5823. Fax: + 17065425771. \\ e-mail: keverett@calc.vet.uga.edu or kdeeverett@hotmail.com
}

Keywords: Chlamydia, PCR-RFLP, rRNA, human pathogens, animal pathogens

\section{INTRODUCTION}

The members of the order Chlamydiales are obligately intracellular bacteria that are proven or suspected pathogens of vertebrates. They cause reproductive, respiratory, cardiovascular, gastrointestinal or systemic disease, as well as conjunctivitis, arthritis and encephalitis (Birtles et al., 1997; Everett \& Andersen, 1997; Kahane et al., 1996, 1998; Lieberman et al., 1997). Recent reclassification of Chlamydiales identified four families: Parachlamydiaceae, Simkaniaceae, Waddliaceae and Chlamydiaceae (Everett et al., 1999; Rurangirwa et al., 1999). In the reclassification by Everett et al. (1999), more than 60 Chlamydiaceae strains belonging to Chlamydia trachomatis, Chlamydia psittaci, Chlamydia pneumoniae and Chlamydia pecorum were regrouped into two genera and nine species based on differences in phenotype, 16S rRNA and 23S rRNA. All species of Chlamydiaceae are recognized by monoclonal antibodies (mAbs) that

\footnotetext{
†Present address: Department of Medical Microbiology and Parasitology, College of Veterinary Medicine, University of Georgia, Athens, GA 30602-7371, USA.
}

detect the LPS trisaccharide epitope $\alpha \mathrm{Kdo}-(2 \rightarrow 8)$ $\alpha \mathrm{Kdo}-(2 \rightarrow 4)-\alpha \mathrm{Kdo}$ (Löbau et al., 1995), and under natural conditions each of the species has a relatively limited host range and a relatively limited disease range. Because many animals are host to more than one chlamydial species, a simple technique that distinguishes each Chlamydiaceae species is needed for taxonomic, epidemiological and pathological studies and for improved diagnostic capability.

Efforts to develop routine species identification of chlamydiae have been ongoing since the early days of chlamydial research. Early methods relied on presumed tissue or host affinities, presumed unique epidemiology, or on specific serology, all characteristics of host response to chlamydiae. In the mid-1960s, phenotypic traits of specific chlamydial strains were identified: glycogen accumulation and sulfadiazine sensitivity (Gordon \& Quan, 1965; Lin \& Moulder, 1966). These characteristics and inclusion morphology became the basis for the description and differentiation of C. trachomatis and C. psittaci species (Page, 1968). Later, DNA-DNA reassociation, serology and/or morphology of the infectious form were used to identify the new species $C$. pneumoniae and $C$. pecorum 
(Cox et al., 1988; Fukushi \& Hirai, 1989, 1992; Grayston et al., 1989). Recent availability of $16 \mathrm{~S}$ and 23S rRNA sequence data has made it possible not only to classify all currently known Chlamydiaceae strains into nine species, but also to use 'signature sequences' for rapid identification of species using PCR and DNA sequencing (Everett et al., 1999). Methods other than sequencing, however, are needed for identification of species because DNA sequencing is limited to specialized laboratories.

Detection of many strains, groups of strains and species has been possible using mAbs, PCR, PCRRFLP or DNA hybridization procedures (e.g. Andersen, 1991; Black, 1997; Kaltenböck et al., 1997; Morre et al., 1998; Sayada et al., 1995; Vretou et al., 1996; Wang et al., 1985). However, these assays were not designed for speciation per se, so when a test fails to identify an isolate, additional effort must be invested. $C$. trachomatis and $C$. pneumoniae can be identified with commercially available mAbs. Species identification of $C$. trachomatis may also use mAbs that recognize a linear, variable-segment-IV epitope in the major outer-membrane protein (MOMP) (Batteiger et al., 1996). However, the epitope recognized by these mAbs is also present in the MOMP of Chlamydia muridarum and Chlamydia suis (Everett et al., 1999). With the change in classification, these $\mathrm{mAbs}$ are no longer species-specific but are, instead, genus-specific. Other mAbs previously characterized as being genus-specific must now be described as family-specific (Everett et al., 1999). These mAbs recognize an LPS epitope in all of the species mentioned above and also in species belonging to the new genus Chlamydophila, which includes C. pecorum, C. pneumoniae, C. psittaci, Chlamydophila abortus, Chlamydophila caviae and Chlamydophila felis.

DNA-based tests for chlamydiae generally target ompA, plasmid or rDNA. Nested PCR and PCRRFLP methods have been developed to identify two to four chlamydial species (Holland et al., 1990; Kaltenböck et al., 1997; Meijer et al., 1997; Messmer et al., 1997; Tong \& Sillis, 1993). Examination of $>50$ complete ompA sequences, however, indicates that nested PCR procedures cannot satisfactorily be expanded to distinguish all nine species because of the excess diversity of this gene. PCR-RFLP targeting of the rRNA operon (Meijer et al., 1997) has differentiated four chlamydial species with sub-groups in both C. trachomatis and C. psittaci. The primers that are used in that test generate $a \geqslant 800 \mathrm{bp}$ PCR product spanning the $16 \mathrm{~S}-23 \mathrm{~S}$ ribosomal intergenic spacer. This $800 \mathrm{bp}$ segment has too many restriction sites for identification of nine species. Meijer's 23S primer also has a $2-4$ base mismatch with chlamydial 23S rRNA genes, which reduces both sensitivity and specificity.

The rRNA operon, particularly the $16 \mathrm{~S}-23 \mathrm{~S}$ intergenic spacer, is an appropriate target for PCRRFLP identification of species of Chlamydiaceae because it is a phylogenetic marker for the nine chlamydial species and contains conserved sequence interspersed with species-specific segments (Everett \& Andersen, 1997; Everett et al., 1999). In the present report, rDNA sequences from over 50 Chlamydiaceae strains representing all nine species were used as a basis to design PCR primers and to select enzymes for a PCR-RFLP method of identification that would distinguish the nine chlamydial species. Sizes of the PCRRFLP fragments were consistent with reported DNA sequences. Comparative amplification using an alternative DNA polymerase made it possible to also detect mycoplasmas which may contaminate host-cell cultures or chlamydial preparations. This PCR-RFLP identification method has taxonomic, epidemiological and clinical value.

\section{METHODS}

Bacterial strains. Twenty-five strains of Chlamydiaceae that had been previously characterized using microimmunofluorescence, serology, ompA sequence analysis, RFLP, DNA hybridization and/or in vitro growth were used in this study (Table 1). The NADC strains were grown in Vero or McCoy cell cultures or in embryonating chicken eggs (Andersen, 1991) (Table 1). Ten mycoplasmas and DNA from other chlamydial isolates, Legionella pneumophila and Simkania negevensis were provided by laboratories where they had been characterized or isolated (Table 1). The first preparation of Simkania DNA proved to contain template from Chlamydia trachomatis L2/434/BU that was being grown in the same laboratory. Upon discovery of the contamination in the course of this study, Simkania from an earlier passage was obtained, confirmed to be free of contamination, and used in subsequent analyses. In addition, a plasmid clone was used that contained an rRNA segment from Mycoplasma orale (Everett \& Andersen, 1997).

DNA template preparation. Chlamydial template DNA was prepared by alkaline lysis. The first step in alkaline lysis was to pellet chlamydiae and/or chlamydial-infected cells by centrifugation $(10000 \mathrm{~g})$. The pellet was resuspended in $30 \mathrm{mM}$ Tris $\mathrm{pH} 9 \cdot 0,10 \mathrm{mM}$ EDTA, pH 9.0, $50 \mathrm{mM}$ DTT and incubated for $1 \mathrm{~h}$ at $37^{\circ} \mathrm{C}$. An equal volume of $1 \%$ Nonidet P-40 was added to each sample, and $5 \mu$ DNAsefree RNAse $(2 \mu \mathrm{g})$ (Boehringer Mannheim) was added to each $200 \mu \mathrm{l}$ mixture. This mixture was incubated $1 \mathrm{~h}$ at $37^{\circ} \mathrm{C}$, extracted with phenol/chloroform, and extracted with chloroform (Sambrook et al., 1989).

PCR conditions. Primers 16SF2 (5' CCGCCCGTCACATCATGG $\left.3^{\prime}\right)$ and 23R (5' TACTAAGATGTTTCAGTTC $\left.3^{\prime}\right)$ were selected based on their conservation among all known Chlamydiaceae strains and on taxon-specific sequence variation within the predicted PCR amplicon (Everett \& Andersen, 1997). Primer 16SF2 was located at approximately nucleotide position 1400 in the chlamydial 16S rRNA gene; primer 23R was located at approximately nucleotide position 200 in the chlamydial 23S rRNA gene (Everett \& Andersen, 1997). Primer 23R had a 3 base mismatch with the Simkania sequence. These primers were used to produce PCR amplicons using $0.25 \mu \mathrm{g}$ of each DNA template. Templates were amplified in a GeneAmp PCR System 9600 thermocycler using PCR Core Reagents, AmpliTaq DNA polymerase and/or AmpliTaq Gold DNA polymerase (Perkin-Elmer). Reaction mixes were prepared on ice, and each $50 \mu$ mixture consisted of $1 \times$ GeneAmp 
Table 1. Strain references and sources

Abbreviations: ${ }^{T}$ Type strain for this species; NADC $=$ USDA, Agriculture Research Service, National Animal Disease Center, Avian and Swine Respiratory Disease Research Unit, Ames, IA, USA; NVSL = USDA, Animal and Plant Health Inspection Service, National Veterinary Services Laboratories, Diagnostic Virology Laboratory, Ames, IA, USA.

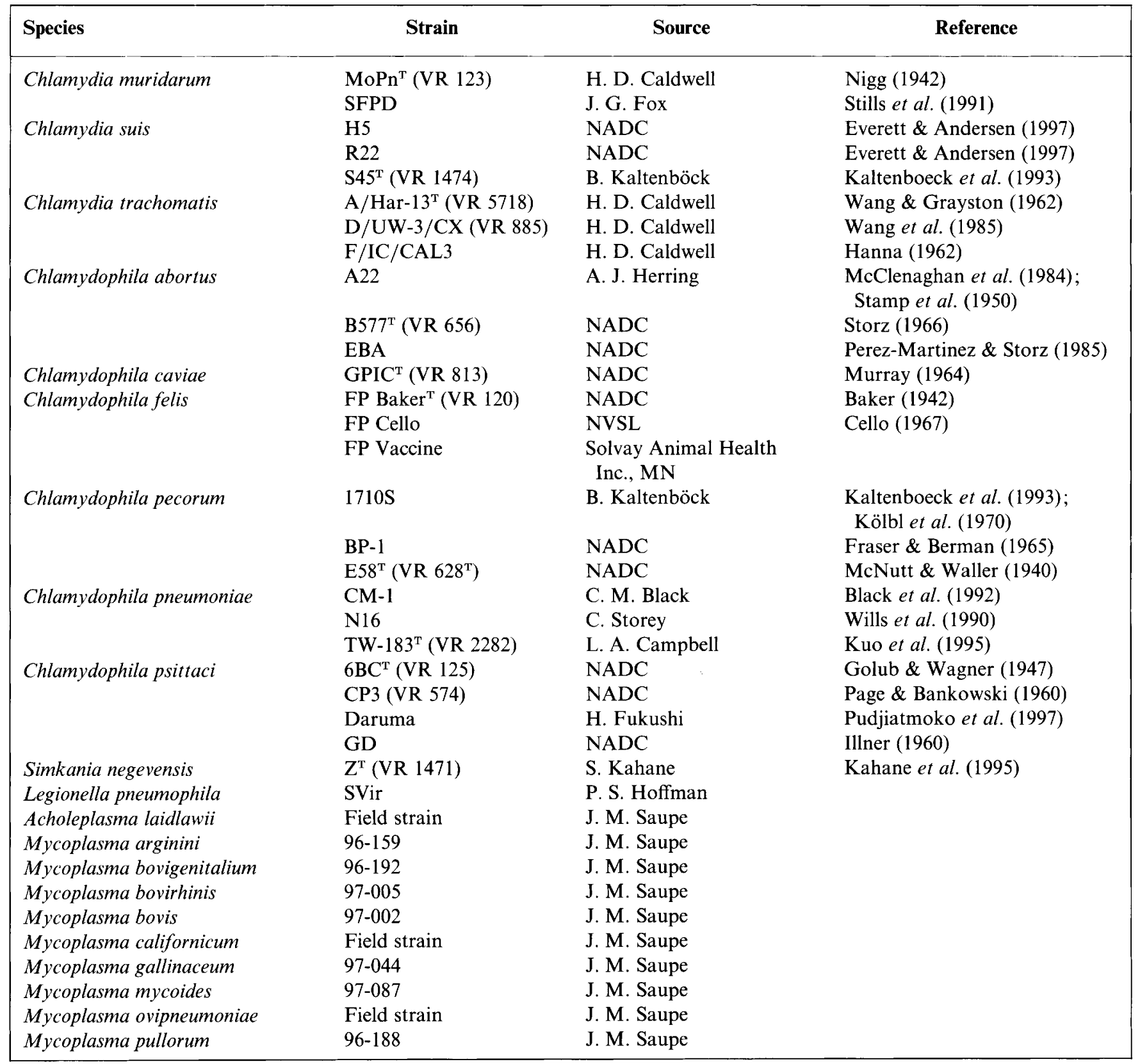

PCR Buffer Il, $2.5 \mathrm{mM} \mathrm{MgCl}_{2}, 0 \cdot 15 \mu \mathrm{M}$ each primer, $200 \mu \mathrm{M}$ each dNTP and $0 \cdot 25 \mu \mathrm{l}(1 \cdot 25 \mathrm{U}) \mathrm{DNA}$ polymerase. PCR amplicons for restriction analysis were produced using AmpliTaq DNA polymerase and 35 cycles of amplification: $25 \mathrm{~s}$ at $94^{\circ} \mathrm{C}, 15 \mathrm{~s}$ at $50^{\circ} \mathrm{C}$, and $30 \mathrm{~s}$ at $72{ }^{\circ} \mathrm{C}$, followed by incubation for $5 \mathrm{~min}$ at $72^{\circ} \mathrm{C}$. The specificity of the shlamydial primers was tested using both AmpliTaq DNA polymerase and AmpliTaq Gold DNA polymerase. Optimal annealing specificity was determined using seven duplicate sets of template and annealing temperatures of $50,52,54,56$, 60,64 or $66^{\circ} \mathrm{C}$. Several sets were also tested with higher annealing temperatures. PCR cycling using both enzymes was done simultaneously at each temperature, except that AmpliTaq Gold cycling was directly preceded by a $5 \mathrm{~min}$ incubation at $94^{\circ} \mathrm{C}$. A modified three-stage PCR cycling procedure was also developed that reduced the amplification of non-chlamydial PCR product but not the amount of chlamydial product. This modified procedure took advantage of improved techniques for using AmpliTaq Gold (Perkin-Elmer technical bulletin 771601-001, 1997). The three-stage procedure consisted of a pre-cycling $10 \mathrm{~min}$ enzyme activation stage at $95^{\circ} \mathrm{C}$, a 10 -cycle amplification stage using $54^{\circ} \mathrm{C}$ annealing, and a 30 -cycle amplification stage using $52^{\circ} \mathrm{C}$ annealing. 
Sequence comparison to identify restriction enzymes. Cleavage sites for restriction enzymes were identified in 41 aligned chlamydial sequences that spanned the ribosomal $16 \mathrm{~S}-23 \mathrm{~S}$ intergenic spacer (Everett \& Andersen, 1997). The sequence analysis programs MAP, PILEUP and PRETTY were used (Genetics Computer Group, 1994). Restriction enzymes were selected based on cleavage site conservation within the nine chlamydial species and predicted sizes of fragments (Table 2)

Restriction analysis and gel electrophoresis. Restriction enzymes $A c i \mathrm{I}, B c l \mathrm{I} B f a \mathrm{I}, H p a \mathrm{I}, S f c \mathrm{I}$ (New England Biolabs) DdeI and RsaI (Boehringer Mannheim) were used at a ratio of $1 \mathrm{U}$ enzyme to $3 \mu \mathrm{l}$ PCR product in each $10 \mu \mathrm{l}$ reaction mix, according to the manufacturers' instructions. Restriction fragments and DNA Molecular Weight Marker VI (Boehringer Mannheim) were separated by electrophoresis in VisiGel separation matrix (Stratagene). DNA bands in the VisiGel matrix were most effectively detected by including a small amount of ethidium bromide in the gel mix. Two other typical staining techniques were unsatisfactory with VisiGel: ethidium bromide in the running buffer only partially diffused into the gel and smeared the DNA bands; gels stained by immersion resisted destaining. Running conditions for these minigels in TAE were $100 \mathrm{~mA}$ for $15 \mathrm{~min}$.

Optimization of PCR amplification conditions for comparison of chlamydial and mycoplasma amplicon production was carried out in $1.5 \%$ agarose gels and with $1 \mathrm{~kb}$ DNA Ladder (Gibco Life Technology). DNA bands were visualized using ethidium bromide.

\section{RESULTS}

\section{PCR and restriction analysis of 25 Chlamydiaceae strains}

Sequence analysis predicted that primers $16 \mathrm{SF} 2$ and 23R would produce a PCR amplicon with restriction endonuclease sites that would distinguish chlamydial species by PCR-RFLP (Table 2). Using these primers and an annealing temperature of $50^{\circ} \mathrm{C}$, AmpliTaq DNA polymerase produced a single amplicon from all of the Chlamydiaceae. The size of the PCR product was $600 \mathrm{bp}$, using template from two strains of Chlamydia muridarum and three strains each of Chlamydia suis and Chlamydia trachomatis. A 585 bp PCR product was produced from Chlamydophila caviae, three strains each of Chlamydophila abortus, Chlamydophila felis, Chlamydophila pecorum and Chlamydophila pneumoniae, and four strains of Chlamydophila psittaci. These conditions were also used to amplify PCR product from three control-DNA templates: Legionella pneumophila, Simkania and a cloned rRNA segment of Mycoplasma orale. Although the Simkania products were predicted to be 65 bases longer than the Chlam$y$ dia products, all of the products examined by electrophoresis appeared to be approximately the same size, except that multiple bands were produced from the plasmid clone of $M$. orale and from $L$. pneumophila (not shown).

Restriction analysis of 24 of the 25 Chlamydiaceae PCR products using $A c i \mathrm{I}, B c l \mathrm{I}, B f a \mathrm{I}, H p a \mathrm{I}, S f c \mathrm{I}, D d e \mathrm{I}$ and $R s a$ I resulted in fragment sizes that were fully consistent with fragment sizes predicted by sequence analysis (Fig. 1). Chlamydial restriction fragments could be readily distinguished from $M$. orale and $L$. pneumophila fragments by size. Extra fragments in Simkania and $C$. pneumoniae N16 were not fully consistent with sequence predictions (Fig. 1, Table 2). Optimization was required before the N16 bands could be resolved (see below). Examination of Table 2 suggested that extra Simkania fragments might be products from $C$. trachomatis $\mathrm{L} 2 / 434 / \mathrm{BU}$. To test this, the Simkania preparation and a different preparation of Simkania DNA were PCR amplified using AmpliTaq and also using AmpliTaq Gold. When AmpliTaq was used, both templates produced PCR products, but the products differed in size: the Simkania preparation used in Fig. 1 generated a product that was identical in size to chlamydial products; the new Simkania preparation generated a distinctly larger product (not shown). Sequence analysis of the AmpliTaq products confirmed that the apparent Simkania PCR product in Fig. 1 actually derived from contaminating $C$. trachomatis $\mathrm{L} 2 / 434 / \mathrm{BU}$ template. This template was preferentially amplified over the Simkania template because the primers were considerably more specific for L2/434/BU. Sequence analysis of the L2/434/BU product was unambiguous. Sequence analysis of AmpliTaq mismatch-amplified PCR product from the uncontaminated Simkania preparation was also unambiguous, matching sequence data previously obtained for Simkania. When AmpliTaq Gold was used, the new Simkania preparation produced no PCR product at all, indicating that this enzyme improved the specificity of the amplification (Fig. 2).

\section{Increasing specificity to reduce amplification of mycoplasmas}

DNA from the $C$. pneumoniae N16 specimen produced a mixture of PCR-RFLP fragments, some predicted and some not predicted by rDNA sequence analysis (Fig. 1, Table 2). N16 fragment sizes were predicted to be nearly identical to those for other strains of $C$. pneumoniae (Table 2). Because the strain was prepared in cell culture, contamination of the sample with mycoplasmas was suspected. To determine if mycoplasmas could be a problem for chlamydial PCRRFLP analysis, 10 Mollicutes template DNAs were obtained for PCR specificity studies: nine field isolates from the family Mycoplasmatales and one from Acholeplasmatales. A positive control was prepared from a pellet of C. psittaci-NJ1-infected Vero cells and included. DNA from $L$. pneumophila and the new preparation of Simkania were also used (Fig. 2). To enhance chlamydial template specificity, two method changes were used: first a hot-start amplification technique (AmpliTaq Gold) vs the standard amplification technique (AmpliTaq), and then also changes in annealing temperature (Fig. 2). 
Table 2. Predicted restriction endonuclease fragments of chlamydial 16 SF2/23R amplicons, based on rDNA sequence analyses

Products that do not cut are shown in bold. Sizes are rounded to nearest 5 or 10 bases.

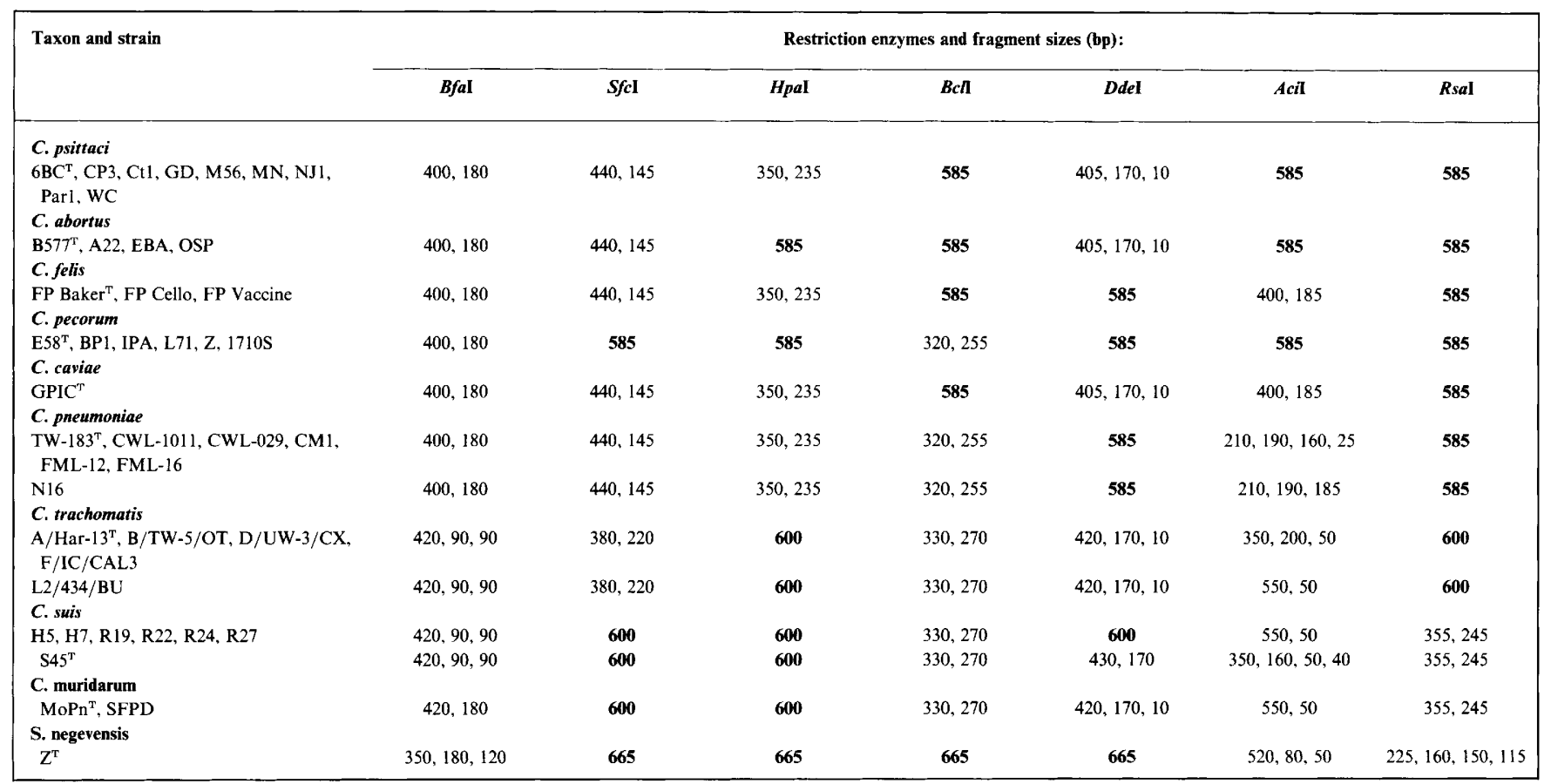

With AmpliTaq, Acholeplasma laidlawii produced little or no PCR product at any annealing temperature. At the highest possible annealing temperature $\left(72^{\circ} \mathrm{C}\right.$, because PCR extension took place at $72{ }^{\circ} \mathrm{C}$ ), neither chlamydial nor mycoplasma template generated PCR products. Annealing temperatures of $64^{\circ} \mathrm{C}$ and $62{ }^{\circ} \mathrm{C}$ produced non-specific amplicons of many sizes from most templates (not shown). With annealing of $60^{\circ} \mathrm{C}$ (not shown) and $56^{\circ} \mathrm{C}$ (Fig. 2), an approximately $600 \mathrm{bp}$ product was amplified from all chlamydial and non-chlamydial templates except $A$. laidlawii and two Mycoplasmatales templates; low molecular mass PCR artifacts were apparent. The low molecular mass artifacts were not present with $54{ }^{\circ} \mathrm{C}$ annealing. With $52{ }^{\circ} \mathrm{C}$ and $50{ }^{\circ} \mathrm{C}$ annealing, all chlamydiae and $\mathrm{Myco}-$ plasmatales yielded single-band PCR products with AmpliTaq, although the amount of Mycoplasma mycoides and Mycoplasma arginini products were somewhat reduced at $52{ }^{\circ} \mathrm{C}$.

In contrast, with AmpliTaq Gold and annealing at $52{ }^{\circ} \mathrm{C}$, only 2 mycoplasmas were amplified (Fig. 2, Table 3). Chlamydial DNA was amplified using $50-56^{\circ} \mathrm{C}$ annealing temperatures and PCR artifacts were not generated. With $\geqslant 54^{\circ} \mathrm{C}$ annealing, mycoplasma PCR products were barely detectable; however, chlamydial and L. pneumophila PCR products were still readily apparent (Fig. 2, Table 3 ). The $L$. pneumophila amplification suggested that the L. pneumophila sequence had significant homology with both of the chlamydial primers. This homology was confirmed by sequence analysis (Table 3 ).

Because specificity was improved with use of AmpliTaq Gold and $52^{\circ} \mathrm{C}$ and $54^{\circ} \mathrm{C}$ annealing (Fig. 2 ), a modified three-stage PCR cycling procedure was used to more specifically amplify $C$. pneumoniae N16 template so that it could be re-examined using PCRRFLP. This procedure was designed to improve specificity for N16 without a quantitative reduction in product. The amount of improvement in N16 amplification, relative to apparent N16 fragments in Fig. 1, could be readily assessed by electrophoresis of $\mathrm{AciI}$ fragments. $A c i$ was predicted to cut N16 PCR product into three fragments, each approximately $200 \mathrm{bp}$ long (Table 2). The $200 \mathrm{bp}$ chlamydial AciI fragments stained intensely with ethidium bromide when the three-stage N16 amplicon was used, but an uncleaved $650 \mathrm{bp}$ band was still evident (Fig. 3). In Fig. 1, 200 bp Aci I products had been almost undetectable. In Fig. 1, four N16 bands had been distinctly inconsistent with N16 sequence data (Table 2): the 650 bp AciI band, $500 \mathrm{bp} \mathrm{DdeI}$ band, $600 \mathrm{bp} \mathrm{HpaI}$ band and $500 \mathrm{bp} \mathrm{RsaI}$ band. With the three-stage N16 product, the intensities of these bands were greatly reduced (Fig. 3). In addition, a $430 \mathrm{bp} \mathrm{BfaI}$ band showed itself to be a doublet of N16 and a non-chlamydial fragment, indicating that a $B f a I$ site was conserved in both the chlamydial and the non-chlamydial products.

Direct DNA sequence analysis of the uncleaved $650 \mathrm{bp}$ 


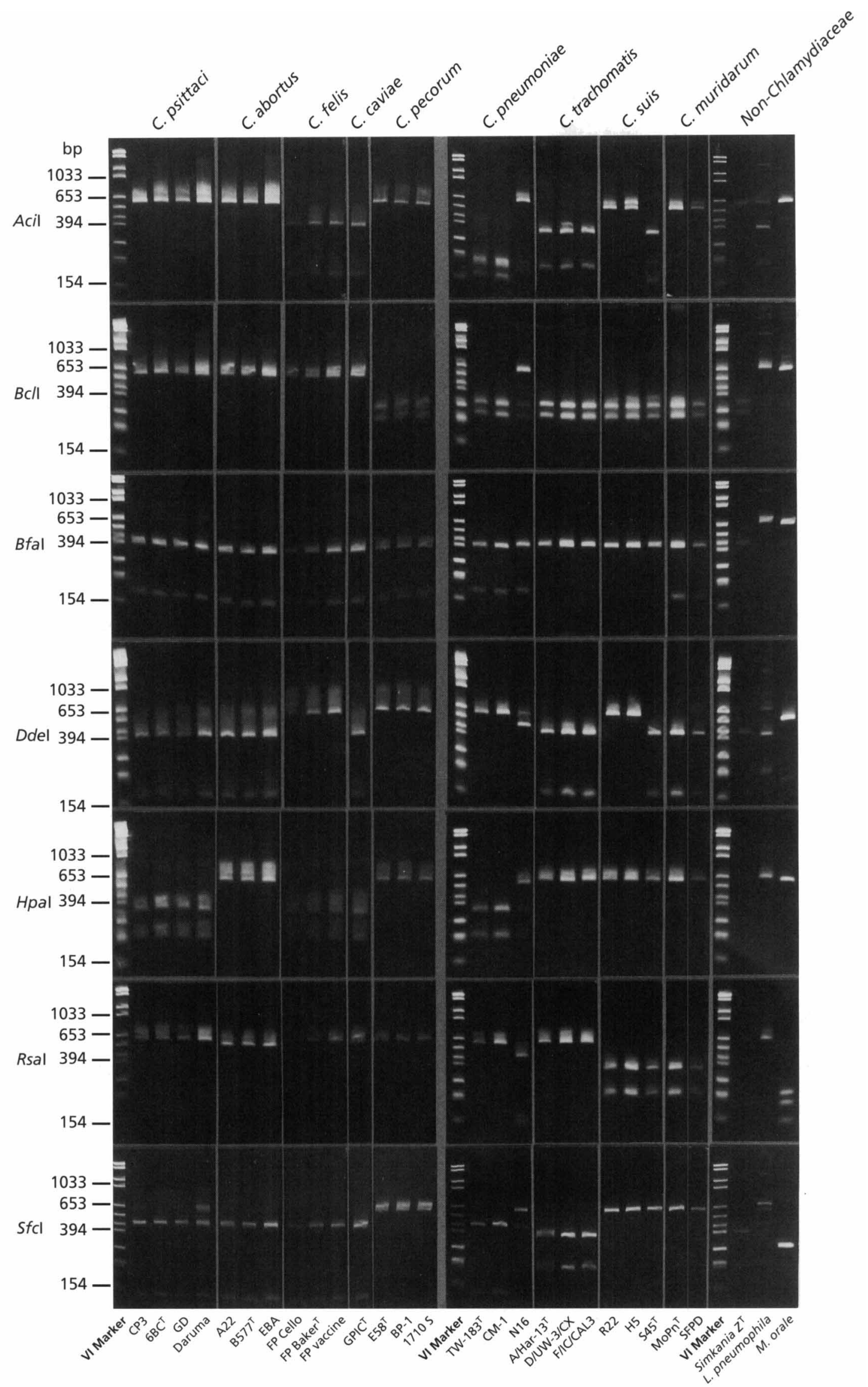



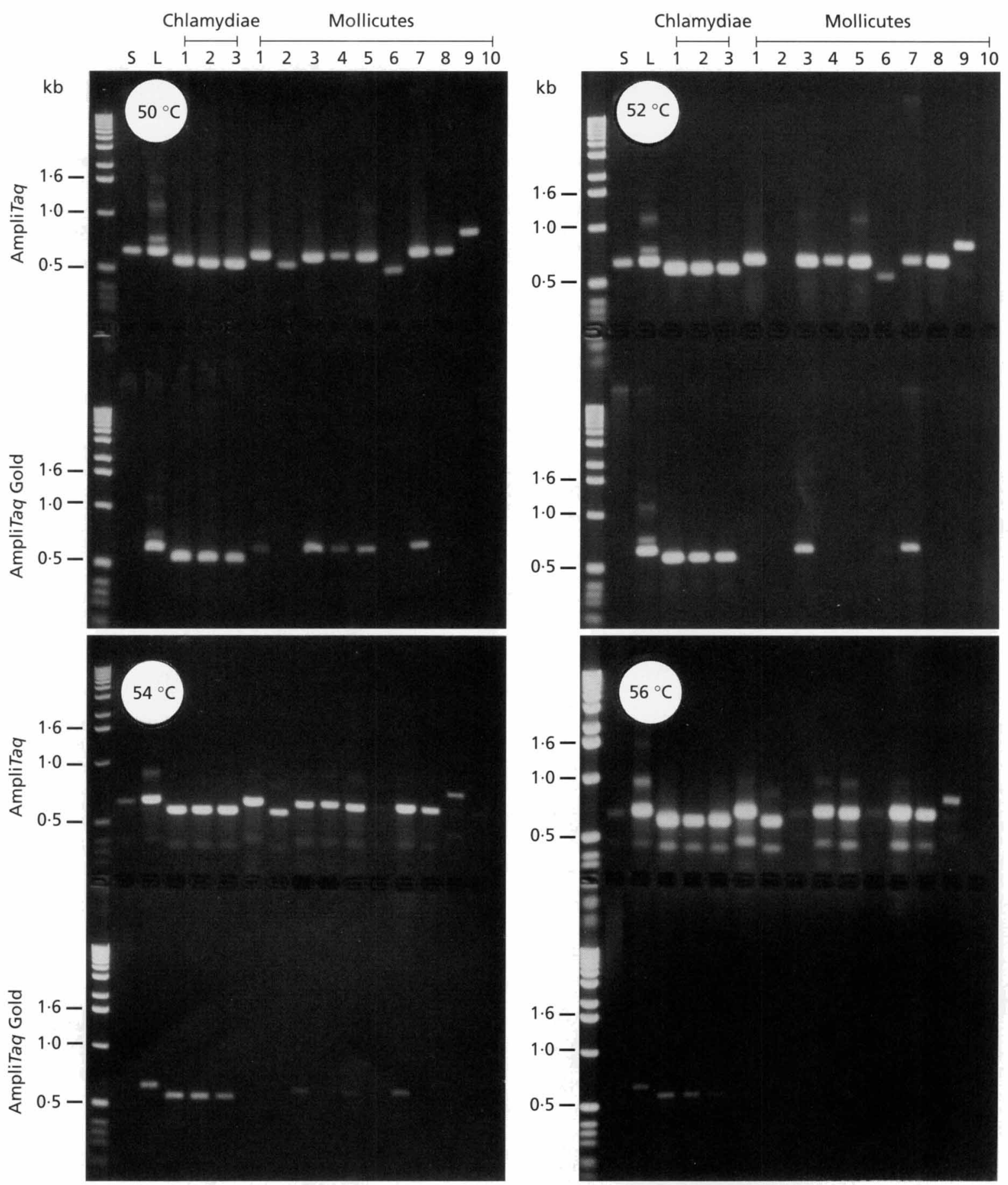

Fig. 2. Control of mismatch $P C R$ amplification. A pure culture of Simkania was used for this analysis. Identical template sets were PCR amplified, as shown, at various annealing temperatures using either AmpliTaq Gold (immediately preceded by a 5 min activation of AmpliTaq Gold at $94^{\circ} \mathrm{C}$ ) or AmpliTaq. Lanes - S, Simkania; L, L. pneumophila; Chlamydiae: 1, NJ1 whole infected-cell nucleic acid preparation with RNase added to the PCR amplification mix; 2, NJ1 whole infected-cell RNA and DNA; 3, NJ1 whole infected-cell DNA. Mollicutes: 1, Mycoplasma pullorum; 2, Mycoplasma mycoides; 3, Mycoplasma bovirhinis; 4, Mycoplasma bovigenitalium; 5, Mycoplasma gallinaceum; 6, Mycoplasma arginini; 7 , Mycoplasma bovis; 8, Mycoplasma californicum; 9, Mycoplasma ovipneumoniae; and 10, Acholeplasma laidlawii.

Fig. 1. PCR-RFLP of 25 Chlamydiaceae strains distinguishes nine species, using AmpliTaq and $50{ }^{\circ} \mathrm{C}$ annealing. Three nonChlamydiaceae templates were also used. Amplicons were generated with primers $16 \mathrm{SF} 2$ and 23R. Restriction enzymes were selected on the basis of predicted fragment sizes (Table 2). The Simkania preparation in this analysis contained a small amount of $C$. trachomatis L2/434/BU template. 
Table 3. Reduced mismatch amplification using AmpliTaq Gold, with primers $16 \mathrm{SF} 2$ and $23 \mathrm{R}$

PCR products resulted from all of these templates when AmpliTaq was used, but only from the templates indicated by ' + ' when AmpliTaq Gold was used. Mismatches were $\geqslant 5$ bases away from the 3 ' end of the primer, except where indicated. Detectable PCR amplicon formation is shown as a function of annealing temperature. NA, Not available; -, no PCR product.

\begin{tabular}{|c|c|c|c|c|c|c|}
\hline \multirow[t]{2}{*}{ Template DNA } & \multirow[t]{2}{*}{$\begin{array}{l}\text { Strain (sequence } \\
\text { accession no.) }\end{array}$} & \multicolumn{2}{|c|}{$\begin{array}{l}\text { No. mismatched } \\
\text { bases in primer: }\end{array}$} & \multirow[t]{2}{*}{$\begin{array}{l}\text { Strain, this } \\
\text { study }\end{array}$} & \multicolumn{2}{|c|}{$\begin{array}{c}\text { Amplification } \\
\text { at: }\end{array}$} \\
\hline & & 16S2F & 23R & & $50{ }^{\circ} \mathbf{C}$ & $56{ }^{\circ} \mathrm{C}$ \\
\hline Chlamydiaceae & All strains & 0 & 0 & All & + & + \\
\hline M. bovis & Donetta $^{\mathrm{T}}$ (U02968) & 2 & NA & $97-002$ & + & - \\
\hline M. californicum & ST-6 (M24582) & 3 & NA & Field strain & - & - \\
\hline$M$. hyorhinis & ATCC 17981 (M24658) & 1 & 1 & NA & + & - \\
\hline M. mycoides & Eight strains & $2 *$ & $\mathrm{NA}$ & $97-087$ & - & - \\
\hline Other Mycoplasmatales & All strains & 1 & NA & All & + & - \\
\hline A. laidlawii & $\begin{array}{l}\text { JA1 and PG8 (M23932 } \\
\text { and U14905) }\end{array}$ & $3^{*}$ & NA & Field strain & - & - \\
\hline S. negevensis & $\mathrm{Z}^{\mathrm{T}}(\mathrm{U} 68460)$ & 0 & $3 \dagger$ & $Z^{\mathrm{T}}$ & - & - \\
\hline L. pneumophila & Many strains & 1 & $1 \dagger$ & SVir & + & + \\
\hline
\end{tabular}

* $3^{\prime}$ end mismatch.

$\dagger$ Determined in this study.

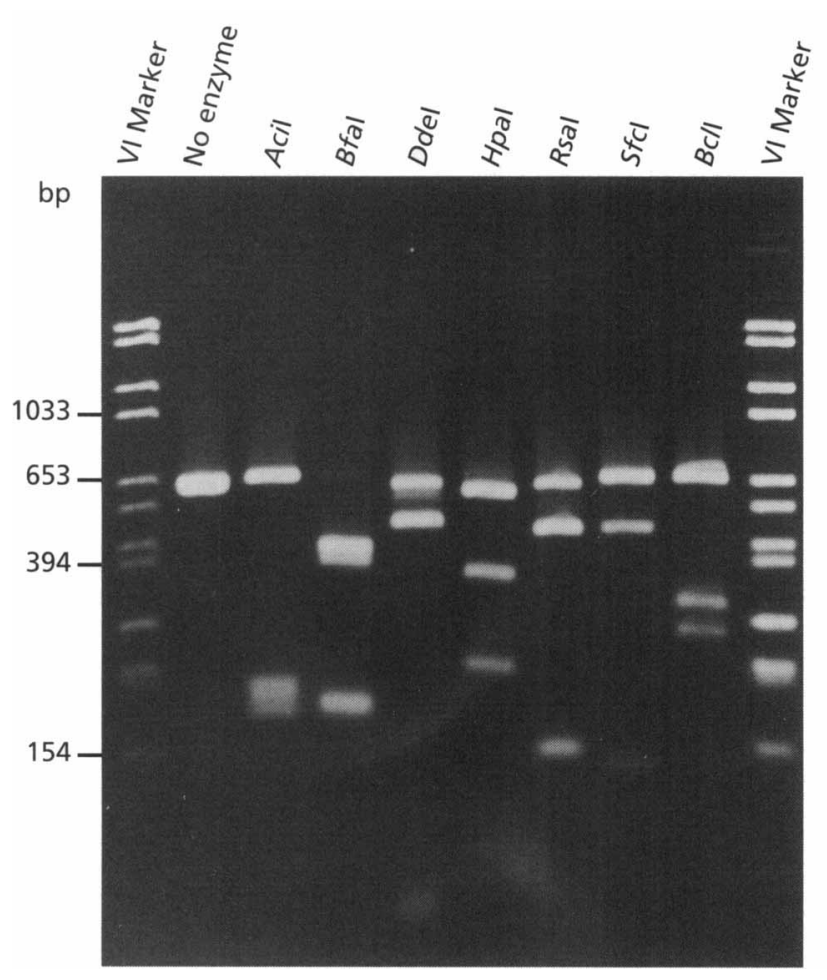

Fig. 3. Optimized $P C R$ of $C$. pneumoniae $\mathrm{N} 16$ to reduce mismatch amplification of $M$. hyorhinis template. AmpliTaq Gold and the three-stage PCR amplification procedure were used $\left(10 \mathrm{~min}\right.$ enzyme activation at $95^{\circ} \mathrm{C}$; 10 -cycle amplification with $54{ }^{\circ} \mathrm{C}$ annealing; 30-cycle amplification with $52{ }^{\circ} \mathrm{C}$ annealing). Comparison of this analysis with predicted N16 fragment sizes in Table 2 and with the intensity of predicted N16 fragments in Fig. 1 indicated that the proportion of N16-M. hyorhinis fragments increased with this procedure.
AciI PCR product from N16 unambiguously showed that the non-chlamydial template in this specimen was Mycoplasma hyorhinis. Mapping of a $16 \mathrm{SF} 2 / 23 \mathrm{R}$ contig formed from previously reported $M$. hyorhinis sequences (GenBank accession nos X68421 and X58555) showed that $M$. hyorhinis had a 1 base mismatch with each chlamydial primer and that the predicted $M$. hyorhinis RFLP fragments could account for observed non-N16 fragments in the N16 lanes of Figs 1 and 3.

\section{DISCUSSION}

This study provided a PCR-RFLP method that can be used as a rapid, specific and inexpensive procedure for speciating Chlamydiaceae isolates. The method uses primer 16SF2, primer 23R and restriction enzymes $A c i \mathrm{I}, B c I \mathrm{I}, B f a \mathrm{I}, D d e \mathrm{I}, H p a \mathrm{I}, R s a \mathrm{I}$ and $S f c \mathrm{I}$, selected on the basis of rDNA sequence analysis of $>50$ chlamydial strains. The primers generated $600 \mathrm{bp}$ amplicons from Chlamydia templates and $585 \mathrm{bp}$ amplicons from Chlamydophila templates. Species-specific RFLP fragment sizes were correctly predicted by sequence analysis (Fig. 1, Table 2). Some diversity was evident in the fragment sizes produced by $C$. suis templates, consistent with the substantial sequence diversity in this species (Everett \& Andersen, 1997).

This study also provided a methodology that discriminates between chlamydiae and mycoplasmas by the substitution of one type of $T a q$ polymerase for another. AmpliTaq DNA polymerase produced amplicons from both mycoplasmas and chlamydiae, due to primer mismatch amplification. In contrast, AmpliTaq 
Gold DNA polymerase, which is heat activated, preferentially amplified chlamydial template because the primers matched it exactly. Mycoplasmas from natural sources may be cultured along with chlamydiae when new isolations are made, so the discrimination provided by these enzymes enables chlamydiologists to determine whether mycoplasmas are present in new isolates while using a single test method and primer set.

Primers and restriction enzymes in this study were selected after a comprehensive comparison of sequence data (Everett \& Andersen, 1997). Primers were chosen that produced a relatively short PCR amplicon, improving the probability that amplification would be successful from even old or damaged template. A search of the GenBank database using BLAST in January 1998 showed that the $16 \mathrm{SF} 2$ primer matched 16S rRNA sequences from 59 chlamydial strains, several strains in the order Verrucomicrobiales, and a planctomycete; primer 23R complemented 23S rRNA sequences from $>50$ known chlamydial strains and from a number of chloroplasts. Thus, the selection of these primers should reduce or eliminate mismatch amplification. $\mathrm{Mg}^{2+}$ concentration and $\mathrm{K}^{+}$concentration in the reaction were kept moderate, to prevent EDTA and other compounds that might be added with the template from limiting amplification. When AmpliTaq DNA Gold DNA polymerase was used, amplification was quite specific for chlamydial template (Fig. 2). However, when AmpliTaq DNA polymerase was used, the chlamydial primers amplified most mycoplasma templates, even at elevated annealing temperatures (Fig. 2). The improvement of specificity with AmpliTaq Gold occurred because this enzyme is activated by a temperature-dependent increase in buffer $\mathrm{pH}$ as a first step in the amplification process (Perkin-Elmer technical bulletin 771601-001, 1997). Enhanced specificity provided by AmpliTaq Gold made it possible to identify a small amount of $C$. trachomatis L2/434/BU DNA in a sample of closely related Simkania template. Use of AmpliTaq Gold and a three-stage PCR amplification procedure enhanced the production of $C$. pneumoniae N16 PCR product against a background of mismatch-amplified $M$. hyorhinis product.

It was determined that the mycoplasmas amplified by the chlamydial primers in this study had one or more mismatches with the primers (Table 3). The apparent quantity of mismatch-produced amplicons was inversely related to the actual number of mismatches (especially 3' mismatches). Use of AmpliTaq Gold eliminated most of the mismatch amplification. It did not eliminate $L$. pneumophila amplification, however, because each primer had only a 1 base mismatch, according to $16 \mathrm{~S}$ rRNA data in GenBank and partial sequence analysis of the L. pneumophila $23 \mathrm{~S}$ rRNA gene. Whether a 2 base mismatch could prevent amplification when AmpliTaq Gold was used was not clear. However, the 3 base mismatch of the Simkania template with the $23 \mathrm{R}$ primer clearly prevented mismatch amplification by AmpliTaq Gold.
Mismatch amplification may prove useful for identifying new members of the order Chlamydiales. Primer $16 \mathrm{SF} 2$ matched the 16S rRNA from all four families in Chlamydiales; primer 23R perfectly complemented the 23S rRNA from Chlamydiaceae and Parachlamydiaceae spp., had a 2 base mismatch with the Waddliaceae type species, and a 3 base mismatch with the Simkaniaceae type species. Thus, when AmpliTaq DNA polymerase is used, these primers can be expected to generate an amplicon from the template of a culture of chlamydia-like bacteria. The relatedness of these bacteria to Chlamydiaceae can be determined by direct sequence analysis of these amplicons. Previously, analyses of chlamydia-like isolates were hindered because these bacteria were not recognized by mAbs specific for the Chlamydiaceae. This work indicates that primers $16 \mathrm{SF} 2$ and $23 \mathrm{R}$ can aid in the discovery and characterization of new chlamydial families.

This PCR-RFLP identification method readily distinguished all nine proposed species of Chlamydiaceae and can be performed in most laboratories. Identifications may be confirmed by testing isolates with specific mAbs. Use of this method with AmpliTaq DNA polymerase contrasted with AmpliTaq Gold DNA polymerase discriminates between chlamydial isolates and mycoplasma contaminants. This assay may be useful in recognizing mixed cultures of chlamydiae and will help improve our understanding of chlamydial pathogenesis, taxonomy and epidemiology.

\section{ACKNOWLEDGEMENTS}

We thank Linda Hornung for the isolation of chlamydial isolates from swine and for propagation of other strains. We also thank Carolyn M. Black, Lee Ann Campbell, Harlan D. Caldwell, James G. Fox, Maureen G. Friedman, Hideto Fukushi, Alan J. Herring, Paul S. Hoffman, Bernhard Kaltenböck, Simona Kahane, Janet M. Saupe and Chris Storey for isolates or isolated DNA from chlamydiae and other bacteria.

\section{REFERENCES}

Andersen, A. A. (1991). Serotyping of Chlamydia psittaci isolates using serovar-specific monoclonal antibodies with the microimmunofluorescence test. J Clin Microbiol 29, 707-711.

Baker, J. A. (1942). A virus obtained from a pneumonia of cats and its possible relation to the cause of atypical pneumonia in man. Science 96, 475-476.

Batteiger, B. E., Lin, P. M., Jones, R. B. \& Van Der Pol, B. J. (1996). Species-, serogroup-, and serovar-specific epitopes are juxtaposed in variable sequence region 4 of the major outer membrane proteins of some Chlamydia trachomatis serovars. Infect Immun 64, 2839-2841.

Birtles, R. J., Rowbotham, T. J., Storey, C., Marrie, T. J. \& Raoult, D. (1997). Chlamydia-like obligate parasite of free-living amoebae. Lancet 349, 925-926.

Black, C. M. (1997). Current methods of laboratory diagnosis of Chlamydia trachomatis infections. Clin Microbiol Rev 10, 160-184. 
Black, C. M., Tharpe, J. A. \& Russell, H. (1992). Distinguishing Chlamydia species by restriction analysis of the major outer membrane protein gene. Mol Cell Probes 6, 395-400.

Cello, R. M. (1967). Ocular infections with PLT (Bedsovia) group agents. Am J Ophthalmol 63, 1270-1273.

Cox, R. L., Kuo, C.-C., Grayston, J. T. \& Campbell, L. A. (1988). Deoxyribonucleic acid relatedness of Chlamydia sp. strain TWAR to Chlamydia trachomatis and Chlamydia psittaci. Int $J$ Syst Bacteriol 38, 265-268.

Everett, K. D. E. \& Andersen, A. A. (1997). The ribosomal intergenic spacer and domain I of the $23 \mathrm{~S}$ rRNA gene are phylogenetic markers for Chlamydia spp. Int $J$ Syst Bacteriol 47, 461-473.

Everett, K. D. E., Bush, R. M. \& Andersen, A. A. (1999). Emended description of the order Chlamydiales, proposal of Parachlamydiaceae fam. nov. and Simkaniaceae fam. nov., each containing one monotypic genus, revised taxonomy of the family Chlamydiaceae, including a new genus and five new species, and standards for the identification of organisms. Int $J$ Syst Bacteriol 49, 415-440.

Fraser, C. E. O. \& Berman, D. T. (1965). Type-specific antigens in the psittacosis- lymphogranuloma venereum group of organisms. J Bacteriol 89, 943-948.

Fukushi, H. \& Hirai, K. (1989). Genetic diversity of avian and mammalian Chlamydia psittaci strains and relation to host origin. J Bacteriol 171, 2850-2855.

Fukushi, H. \& Hirai, K. (1992). Proposal of Chlamydia pecorum sp. nov. for Chlamydia strains derived from ruminants. Int $J$ Syst Bacteriol 42, 306-308.

Genetics Computer Group (1994). Program Manual for the Wisconsin Package, version 8. Madison, WI: Genetics Computer Group.

Golub, O. J. \& Wagner, J. C. (1947). Studies on the interference phenomenon with certain members of the psittacosis-lymphogranuloma group of viruses. J Immunol 59, 59-70.

Gordon, F. B. \& Quan, A. L. (1965). Occurrence of glycogen in inclusions of the psittacosis- lymphogranuloma venereumtrachoma agents. $J$ Infect Dis 115, 186-196.

Grayston, J. T., Kuo, C.-C., Campbell, L. A. \& Wang, S.-P. (1989). Chlamydia pneumoniae sp. nov. for Chlamydia sp. strain TWAR. Int J Syst Bacteriol 39, 88-90.

Hanna, L. (1962). Isolation of trachoma and inclusion conjunctivitis viruses in the US. Ann NY Acad Sci 98, 24-30.

Holland, S. M., Gaydos, C. A. \& Quinn, T. C. (1990). Detection and differentiation of Chlamydia trachomatis, Chlamydia psittaci, and Chlamydia pneumoniae by DNA amplification. $J$ Infect Dis 162, $984-987$.

IIIner, V. F. (1960). Zur Frage der Übertragung des Ornithosevirus durch das Ei. Monatsh Veterinaermed 17, 116-117.

Kahane, S., Metzer, E. \& Friedman, M. G. (1995). Evidence that the novel microorganism ' $\mathrm{Z}$ ' may belong to a new genus in the family Chlamydiaceae. FEMS Microbiol Lett 126, 203-208.

Kahane, S., Greenberg, D., Lieberman, D., Dagan, R., Haikin, H., Bir, Y. \& Friedman, M. G. (1996). The novel microorganism " $\mathrm{Z}$ " is capable of infecting humans. In Proceedings of the Third Meeting of the European Society for Chlamydia Research, p. 18. Edited by A. Stary. Bologna: Study Group for STD and Dermatological Microbiology of the Austrian Society for Dermatology and Venerology.

Kahane, S., Greenberg, D., Friedman, M. G., Haikin, H. \& Dagan, R. (1998). High prevalence of $S$. negevensis, a novel chlamydia- like bacterium, in infants with acute bronchiolitis. $J$ Infect Dis 177, 1425-1429.

Kaltenboeck, B., Kousoulas, K. G. \& Storz, J. (1993). Structures of and allelic diversity and relationships among the major outer membrane protein $(o m p A)$ genes of the four chlamydial species. $J$ Bacteriol 175, 487-502.

Kaltenböck, B., Schmeer, N. \& Schneider, R. (1997). Evidence for numerous ompl alleles of porcine Chlamydia trachomatis and novel chlamydial species obtained by PCR. J Clin Microbiol 35, 1835-1841.

Kölbl, O., Burtscher, H. \& Hebenstreit, J. (1970). Polyarthritis bei Schlachtschweinen. Wien Tieraerztl Monatsschr 57, 355-361.

Kuo, C.-C., Jackson, L. A. , Campbell, L. A. \& Grayston, J. T. (1995). Chlamydia pneumoniae (TWAR). Clin Microbiol Rev 8 , 451-461.

Lieberman, D., Kahane, S., Lieberman, D. \& Friedman, M. G. (1997). Pneumonia with serological evidence of acute infection with the chlamydia-like microorganism " $\mathrm{Z}$ ". Am J Respir Crit Care Med 156, 578-582.

Lin, H.-S. \& Moulder, J.W. (1966). Patterns of response to sulfadiazine, D-cycloserine and D-alanine in members of the psittacosis group. $J$ Infect Dis 116, 372-376.

Löbau, S., Mamat, U., Brabetz, W. \& Brade, H. (1995). Molecular cloning, sequence analysis, and functional characterization of the lipopolysaccharide biosynthetic gene $k d t A$ encoding 3deoxy- $\alpha$-D-manno-octulosonic acid transferase of Chlamydia pneumoniae strain TW-183. Mol Microbiol 18, 391-399.

McClenaghan, M., Herring, A. J. \& Aitken, I. D. (1984). Comparison of Chlamydia psittaci isolates by DNA restriction endonuclease analysis. Infect Immun 45, 384-389.

McNutt, S. H. \& Waller, E. F. (1940). Sporadic bovine encephalomyelitis (Buss disease). Cornell Vet 30, 437-448.

Meijer, A., Kwakkel, G. J., deVries, A., Schouls, L. M. \& Ossewaarde, J. M. (1997). Species identification of Chlamydia isolates by analyzing restriction fragment length polymorphism of the 16S-23S rRNA spacer region. $J$ Clin Microbiol 35, 1179-1183.

Messmer, T. O., Skelton, S. K., Moroney, J. F., Daugharty, H. \& Fields, B. S. (1997). Application of a nested, multiplex PCR to psittacosis outbreaks. J Clin Microbiol 35, 2043-2046.

Morre, S. A., Ossewaarde, J. M., Lan, J., van Doornum, G. J., Walboomers, J. M., MacLaren, D. M., Meijer, C. J. \& van den Brule, A. J. (1998). Serotyping and genotyping of genital Chlamydia trachomatis isolates reveal variants of serovars $\mathrm{Ba}, \mathrm{G}$, and $\mathrm{J}$ as confirmed by ompl nucleotide sequence analysis. $J$ Clin Microbiol 36, 345-351.

Murray, E. S. (1964). Guinea pig inclusion conjunctivitis virus. I. Isolation and identification as a member of the psittacosislymphogranuloma-trachoma group. J Infect Dis 114, 1-12.

Nigg, C. (1942). Unidentified virus which produces pneumonia and systemic infection in mice. Science 95, 49-50.

Page, L. A. (1968). Proposal for the recognition of two species in the genus Chlamydia. Jones, Rake, and Stearns, 1945. Int J Sys Bacteriol 18, 51-66.

Page, L. A. \& Bankowski, R. A. (1960). Factors affecting the production and detection of ornithosis antibodies in infected turkeys. Am J Vet Res 21, 971-978.

Perez-Martinez, J. A. \& Storz, J. (1985). Antigenic diversity of Chlamydia psittaci of mammalian origin determined by microimmunofluorescence. Infect Immun 50, 905-910.

Pudjiatmoko, Fukushi, H., Ochiai, Y., Yamaguchi, T. \& Hirai, K. 
(1997). Phylogenetic analysis of the genus Chlamydia based on 16S rRNA gene sequences. Int $J$ Syst Bacteriol 47, 425-431.

Rurangirwa, F. R., Dilbeck, P. M., Crawford, T. B., McGuire, T. C. \& McElwain, T. F. (1999). Analysis of the 16S rRNA gene of micro-organism WSU 86-1044 from an aborted bovine foetus reveals that it is a member of the order Chlamydiales: proposal of Waddliaceae fam. nov., Waddlia chondrophila gen. nov., sp. nov. Int J Syst Bacteriol 49, 577-581.

Sambrook, J., Fritsch, E. F. \& Maniatis, T. (1989). Molecular Cloning : a Laboratory Manual, 2nd edn. Cold Spring Harbor, NY: Cold Spring Harbor Laboratory.

Sayada, C., Andersen, A. A., Storey, C., Milon, A., Eb, F., Hashimoto, N., Hirai, K., Elion, J. \& Denamur, E. (1995). Usefulness of ompl restriction mapping for avian Chlamydia psittaci isolate differentiation. Res Microbiol 146, 155-165.

Stamp, J. T., McEwen, A. D., Watt, J. A. A. \& Nisbet, D. I. (1950). Enzootic abortion in ewes. Vet Rec 62, 251-254.

Stills, H. F., Jr, Fox, J. G., Paster, B. J. \& Dewhirst, F. E. (1991). A "new" Chlamydia sp.strain SFPD isolated from transmissible proliferative ileitis in hamsters. Microbiol Ecol Health Dis 4, S99.
Storz, J. (1966). Psittacosis-lymphogranuloma infection of sheep. Antigenic structures and interrelations of PL agents associated with polyarthritis, enzootic abortion, intrauterine and latent intestinal infections. J Comp Pathol 76, 351-362.

Tong, C. Y. \& Sillis, M. (1993). Detection of Chlamydia pneumoniae and Chlamydia psittaci in sputum samples by PCR. $J$ Clin Pathol 46, 313-317.

Vretou, E., Loutrari, H., Mariani, L. \& 7 other authors (1996). Diversity among abortion strains of Chlamydia psittaci demonstrated by inclusion morphology, polypeptide profiles and monoclonal antibodies. Vet Microbiol 51, 275-289.

Wang, S.P. \& Grayston, J. T. (1962). Classification of trachoma virus strains by protection of mice from toxic death. $J$ Immunol 90, 849-856.

Wang, S.-P., Kuo, C.-C., Barnes, R. C., Stephens, R. S. \& Grayston, J. T. (1985). Immunotyping of Chlamydia trachomatis with monoclonal antibodies. J Infect Dis 152, 791-800.

Wills, J. M., Watson, G., Lusher, M., Wood, D. \& Richmond, S. J. (1990). Characterisation of Chlamydia psittaci isolated from a horse. Vet Microbiol 24, 11-19. 